\title{
PENGARUH CAPITAL INTENSITY, UKURAN PERUSAHAAN, DAN LEVERAGE TERHADAP TAX AVOIDANCE PADA PERUSAHAAN YANG TERDAFTAR DI JAKARTA ISLAMIC INDEX
}

\author{
Rinosa Ari Widagdo ${ }^{1}$, Nawang Kalbuana ${ }^{2)}$, Devia Rahma Yanti ${ }^{3)}$ \\ ${ }^{1,2)}$ Politeknik Penerbangan Indonesia \\ Jl. Raya PLP Curug, Serdang Wetan, Kec. Legok, Tangerang, Banten \\ ${ }^{1)}$ rinosa.ari@ppicurug.ac.id \\ 2) nawang.kalbuana@ppicurug.ac.id \\ ${ }^{3)}$ Fakultas Ekonomi Bisnis, Universitas Pramita Indonesia \\ Binong, Curug, Tangerang, Banten \\ 3) bluesweet15@gmail.com
}

Diterima: 13 Juli 2020. Disetujui: 24 Desember 2020. Dipublikasikan: Desember 2020

\begin{abstract}
Abstrak
Tujuan penelitian ini adalah mengetahui efek pada tax avoidance atas variabel capital intensity, ukuran perusahaan dan leverage. Sampel dari penelitian ini adalah perusahaan yang terdaftar di Jakarta Islamic Indek tahun 2015 sampai dengan 2019. Penelitian ini menggunakan teknik purposive sampling dalam penentuan sampelnya sedangkan untuk melakukan analisis digunakan analisis linier berganda. Hasil penelitian ini mengungkapkan bahwa pada perusahaan yang terdaftar di Jakarta Islamic Indek atas variabel capital intensity memiliki pengaruh positif terhadap tax avoidance sedangkan leverage memiliki pengaruh negatif terhadap tax avoidance. Hal lain yang cukup mengejutkan pada penelitian ini adalah atas variabel ukuran perusahaan khususnya di perusaaan yang terdaftar di Jakarta Islamic Indek tidak berpengaruh terhadap tax avoidance.
\end{abstract}

Kata kunci: tax avoidance, capital intensity, ukuran perusahaan, leverage

\begin{abstract}
The purpose of this study was to find out the effect of tax avoidance on capital intensity variables, company size, and leverage. Samples from this study are companies registered in Jakarta Islamic Index from 2015 to 2019. This research uses a purposive sampling technique in determining the sample while performing analysis used multiple linear analyses. The results of this study revealed that in companies registered in Jakarta Islamic Index on capital intensity variables have a positive influence on tax avoidance while leverage has a negative influence on tax avoidance. Another thing that is quite surprising in this research is the variable size of the company, especially in companies listed in Jakarta Islamic Index does not affect tax avoidance.
\end{abstract}

Keywords: tax avoidance; capital intensity; firm size; leverage

\section{PENDAHULUAN}

Pajak adalah salah satu kewajiban masyarakat kepada negara dan sebagai bentuk partisipasi masyarakat dalam pembangunan tanah air dan negara. Definisi pajak menurut Rochmat Soemitro (Mardiasmo, 2011:1) adalah iuran rakyat kepada kas negara berdasarkan undang-undang (yang dapat dipaksakan) dengan tiada mendapat jasa timbal (kontraprestasi) yang langsung dapat ditunjukan dan yang digunakan untuk membayar pengeluaran umum. Pajak merupakan sumber pendanaan penting bagi perekonomian suatu negara dikarenakan sumber penerimaan negara yang paling potensial dan menempati persentase tertinggi dalam Anggaran Pendapatan dan Belanja 
Negara (APBN) adalah pajak. Pada awal tahun 1984, pemerintah mengubah sistem perpajakan di Indonesia yang awalnya adalah official assessment system berubah menjadi self assessment system. Official assessment system adalah sistem pemungutan pajak yang memberikan tanggung jawab sepenuhnya dalam pemungutan pajak kepada pemerintah, sedangkan self-assessment system adalah suatu sistem pemungutan pajak yang memberikan wewenang wajib pajak dalam menentukan sendiri jumlah pajak yang terhutang setiap tahunnya sesuai dengan peraturan perundang-undangan perpajakan yang berlaku. (Siti Resmi, 2014:11). Dengan diterapkannya self assestment system, wajib pajak diwajibkan untuk menghitung, memperhitungkan, menyetor, dan melaporkan pajaknya sendiri, hal ini menciptakan peluang bagi wajib pajak untuk melakukan penghindaran pajak (tax avoidance) karena sistem tersebut dapat memberikan kesempatan perusahaan untuk menghitung penghasilan kena pajak serendah mungkin, sehingga beban pajak yang ditanggung perusahaan menjadi turun (Ardyansyah dan Zulaikha, 2014).

Tax avoidance adalah usaha meringankan beban pajak dengan tidak melanggar undangundang (Mardiasmo, 2011:8). Tax avoidance biasanya dilakukan oleh wajib pajak badan (perusahaan) karena perusahaan ingin berupaya meminimalisir beban pajaknya agar dapat meningkatkan profitabilitas dan arus kas. Menurut Hanlon dan heitzman (2010), rasio tingkat penghindaran pajak (tax avoidance) dapat dihitung dengan menggunakan proksi diantaranya: Accounting Effective Tax Rate (GAAP ETR), Current Effective Tax Rate (Current ETR), dan Cash Effective Tax Rate (CETR). Meski penghindaran pajak bersifat legal, dari pihak pemerintah tetap tidak menginginkan hal tersebut karena akan mengurangi pendapatan negara. Fenomena penghindaran pajak di Indonesia dapat dilihat dari rasio pajak (tax ratio) negara Indonesia. Rasio pajak menunjukkan kemampuan pemerintah dalam mengumpulkan pendapatan pajak atau menyerap kembali produk domestik bruto (PDB) dari masyarakat dalam bentuk pajak. Semakin tinggi rasio pajak suatu negara, maka semakin baik kinerja pemungutan pajak negara tersebut. Direktorat Jenderal Pajak (DJP) mengungkapkan rasio pajak terhadap produk domestik bruto (PBD) atau tax ratio Indonesia sebesar 10,7 persen pada tahun 2019. Angka itu turun dari tahun 2018 yakni 11,5 persen (CNNIndonesia.com, 2020).

Capital intensity adalah rasio kegiatan investasi yang dimiliki perusahaan dalam bentuk aset tetap. Capital intensity menggambarkan seberapa besar proporsi aset tetap perusahaan dari total asetnya. Capital intensity pada umumnya dapat dihitung dengan menggunakan proksi total aset tetap dibagi dengan total aset yang dimiliki perusahaan (Lanis dan Richardson, 2011 dalam Husnaini et al, 2013). Menurut Rodriguez dan Arias (2012) dalam Ardyansah dan Zulaikha (2014) mengatakan bahwa aset tetap perusahaan memungkinkan perusahaan untuk mengurangi pajaknya akibat dari penyusutan aset tetap setiap tahunnya. Hampir seluruh aset tetap akan mengalami penyusutan yang akan menjadi biaya penyusutan dalam laporan keuangan perusahaan. Sementara biaya penyusutan ini adalah biaya yang dapat dikurangkan dari penghasilan dalam perhitungan pajak perusahaan. Semakin besar biaya penyusutan akan semakin kecil tingkat pajak yang harus dibayarkan perusahaan.

Machfoedz (1994) dalam Suwito dan Herawati (2005) menyatakan bahwa ukuran perusahaan adalah suatu skala yang mengklasifikasikan perusahaan menjadi perusahaan besar dan kecil menurut berbagai cara seperti total aktiva atau total aset perusahaan, nilai pasar saham, rata-rata tingkat penjualan, dan jumlah penjualan. Tahap kedewasaan perusahaan ditentukan berdasarkan total aktiva, semakin besar total aktiva menunjukkan bahwa perusahaan memiliki prospek baik dalam jangka waktu yang relatif panjang. Hal ini menggambarkan bahwa perusahaan lebih stabil dan lebih mampu dalam menghasilkan laba dibanding perusahaan dengan total aktiva yang kecil. Oleh sebab itu beberapa peneliti terdahulu menggunakan total aktiva/aset dalam mengukur ukuran perusahaan. Menurut Munawir (2010:30) rumus ukuran perusahaan adalah logaritma natural total aset. Watts dan Zimmerman (1986) dalam Achmad et al. (2007) menyatakan bahwa manajer perusahaan besar cenderung melakukan pemilihan metode akuntansi yang menangguhkan laba yang dilaporkan dari periode sekarang ke periode mendatang guna memperkecil laba yang dilaporkan.

Leverage merupakan rasio yang menunjukkan besarnya hutang yang dimiliki oleh perusahaan untuk membiayai aset tetapnya. Penambahan jumlah hutang akan mengakibatkan munculnya 
beban bunga yang harus dibayar oleh perusahaan. Komponen beban bunga akan mengurangi laba sebelum kena pajak perusahaan, sehingga beban pajak yang harus dibayar perusahaan akan menjadi berkurang (Adelina, 2012). Menurut Hery (2015:190), rasio solvabilitas atau leverage merupakan rasio yang digunakan untuk mengukur sejauh mana aset perusahaan dibiayai dengan utang. Dengan kata lain, rasio solvabilitas merupakan rasio yang digunakan untuk mengukur seberapa besar beban utang yang harus ditanggung perusahaan dalam rangka pemenuhan aset. Untuk menghitung rasio solvabilitas atau leverage, proksi yang paling umum digunakan yaitu Debt to Total Asset Ratio (DAR) dan Debt to Equity Ratio (DER).

Pada penelitian-penelitian sebelumnya, pengambilan sampel dilakukan pada perusahaan yang terdaftar di dalam indeks-indeks Bursa Efek Indonesia dengan mengkhususkan pada satu bidang sektor. Sedangkan, dalam penelitian ini penulis mengambil obyek saham syariah pada perusahaan yang berbasis syariah dalam kelompok Jakarta Islamic Index (JII) dikarenakan selain sebagai indeks saham syariah yang pertama kali diluncurkan di pasar modal Indonesia, konstituen JII juga hanya terdiri dari 30 saham syariah yang paling likuid tercatat di BEI.

Berdasarkan uraian di atas, maka rumusan masalah yang diangkat pada penelitian ini adalah: Apakah capital intensity, ukuran perusahan, dan leverage berpengaruh terhadap tax avoidance pada perusahaan yang terdaftar di Jakarta Islamic Index (JII) pada periode 2015-2019?

Dari rumusan masalah tersebut penelitian ini dilakukan dengan tujuan untuk mengetahui pengaruh capital intensity, ukuran perusahaan, dan leverage terhadap tax avoidance pada perusahaan yang terdaftar di Jakarta Islamic Index (JII) pada periode 2015-2019.

\section{TINJAUAN PUSTAKA}

\subsection{Modigliani-Miller (MM) Theory (Dengan Pajak)}

Teori MM dengan pajak merupakan kelanjutan dari teori MM tanpa pajak. Di mana di dalam teori ini MM menyimpulkan bahwa penggunaan hutang sebagai sumber pendanaan akan dapat melakukan penghematan pajak karena hutang menimbulkan beban bunga yang dapat digunakan untuk menggurangi pajak yang harus dibayar (Bringham \& Houston, 2006).

\subsection{Tax Avoidance}

Penghindaran pajak (tax avoidance) adalah cara untuk menghindari pembayaran pajak secara legal yang dilakukan oleh wajib pajak dengan cara mengurangi jumlah pajak terhutangnya tanpa melanggar peraturan perpajakan atau dengan istilah lainnya mencari kelemahan peraturan (Hutagaol, 2007). Tax avoidance dalam penelitian ini menggunakan proksi current ETR (Effective Tax Rate). Menurut Siti Normala (2013) current ETR baik digunakan untuk menggambarkan kegiatan penghindaran pajak oleh perusahaan karena current ETR dihitung dari beban pajak kini dengan laba sebelum pajak perusahaan, sehingga dapat mencerminkan strategi penangguhan beban pajak yang dilakukan oleh manajemen perusahaan. Semakin rendah ETR maka menunjukan semakin tingginya tingkat penghindaran pajak yang dilakukan perusahaan. Rumus perhitungan current ETR adalah beban pajak kini dibagi dengan laba sebelum pajak.

\subsection{Capital Intensity}

Capital intensity merupakan kegiatan investasi perusahaan dalam bentuk aset tetap. Dengan kata lain, capital intensity menggambarkan seberapa besar perusahaan menginvestasikan asetnya dalam bentuk aset tetap. Kepemilikan aset tetap dapat mengurangi pembayaran pajak yang dibayarkan perusahaan karena adanya biaya depresiasi yang melekat pada aset tetap. Biaya depresiasi dapat dimanfaatkan oleh manajer untuk meminimumkan pajak yang dibayar perusahaan. Manajemen akan melakukan investasi aset tetap dengan cara menggunakan dana menganggur perusahaan untuk mendapatkan keuntungan berupa biaya depresiasi yang berguna sebagai pengurang pajak (Darmadi, 2013). Hal ini menunjukkan bahwa perusahaan dengan tingkat aset tetap yang tinggi memiliki beban pajak yang lebih rendah. Perusahaan yang lebih menekankan pada investasi berupa aset tetap akan memiliki tarif pajak efektif yang rendah (Gupta dan Newberry, 1997), yang berarti semakin tinggi capital intensity perusahaan maka semakin tinggi penghindaran pajak perusahaan. Penelitian terdahulu yang dilakukan oleh Nyoman Budhi 
Setya Dharma dan Naniek Noviari (2017) serta Ria Rosalia Purnomo (2016) menemukan bahwa capital intensity berpengaruh signifikan terhadap tax avoidance.

Hasil penelitian yang dilakukan oleh Noor, et al (2010) menemukan bahwa capital intensity berpengaruh positif terhadap penghindaran pajak, hal ini sejalan dengan penelitian yang dilakukan oleh Muzakki dan Darsono (2015) tentang pengaruh CSR dan capital intensity terhadap penghindaran pajak yang menyatakan bahwa capital intensity berpengaruh positif terhadap tax avoidance, sedangkan penelitian yang dilakukan oleh Ambarukmi dan Diana (2017) serta Wiguna dan Jati (2017) menemukan bahwa capital intensity tidak berpengaruh terhadap penghindaran pajak.

Capital intensity dalam penelitian ini menggunakan proksi rasio intensitas aset tetap. Menurut Lanis dan Richardson (2011) dalam Husnaini et al (2013) rasio intensitas aset tetap adalah perbandingan aset tetap terhadap total aset sebuah perusahaan, di mana rasio ini menggambarkan proporsi atau seberapa besar aset tetap yang dimiliki perusahaan dari total asetnya.

\subsection{Ukuran Perusahaan}

Ukuran perusahaan menurut Jasmine (2017) merupakan suatu pengukuran yang dapat mengklasifikasikan perusahaan menjadi perusahaan besar dan kecil melalui total aset perusahaan yang dimiliki, nilai pasar saham, rata-rata tingkat penjualan dan jumlah penjualan. Pengaruh karakteristik perusahaan terkait terhadap penghindaran pajak. Semakin besar ukuran perusahaan, maka transaksi yang dilakukan oleh perusahaan akan semakin kompleks. Sehingga, perusahaan dapat memanfaatkan celah-celah untuk melakukan penghindaran pajak dari setiap transaksi yang dilakukan perusahaan (Mayarisa Oktamawati, 2016). Selain itu, perusahaan yang besar cenderung memiliki sumber daya yang lebih besar dibandingkan perusahaan yang memiliki skala lebih kecil untuk melakukan pengelolaan pajak. Sumber daya manusia yang ahli dalam perpajakan diperlukan agar dalam pengelolaan pajak yang dilakukan oleh perusahaan dapat maksimal untuk menekan beban pajak perusahaan. Perusahaan berskala kecil tidak dapat optimal dalam mengelola beban pajaknya dikarenakan kekurangan ahli dalam perpajakan (Nicodeme, 2007 dalam Darmadi, 2013). Jadi semakin besar ukuran perusahan maka tingkat penghindaran pajak yang dilakukan perusahaan juga akan meningkat.

Hasil penelitian yang dilakukan oleh Cahyono, Andini, dan Raharjo (2016) serta Ni Nyoman dan I Ketut (2014) menyatakan bahwa ukuran perusahaan tidak berpengaruh secara signifikan terhadap tax avoidance. Sedangkan Dyreng, Hanlon, \& Maydew (2008) dalam penelitiannya menemukan bahwa ukuran perusahaan berpengaruh negatif terhadap tax avoidance, hasil yang sama juga ditemukan dalam penelitian yang dilakukan oleh Dewi dan Noviari (2017).

Delgado, Rodriguez dan Arias (2012) dalam penelitiannya menggunakan total aset sebagai penentu ukuran perusahaan dikarenakan perusahaan cenderung memiliki arus kas yang positif dan dianggap memiliki kinerja serta prospek yang bagus dalam jangka waktu yang lama bila total aset perusahaan tersebut besar jumlahnya. Selain itu, perusahaan yang beroperasi dengan total aset yang besar juga lebih mampu menghasilkan profit dibandingkan dengan perusahaan dengan total aset yang kecil. Oleh karena itu, total aset merupakan dasar tolak ukur skala suatu perusahaan sehingga dalam penelitian ini, untuk menghitung ukuran perusahaan ditetapkan menggunakan proksi logaritma natural aset tetap.

\subsection{Leverage}

Leverage merupakan rasio yang digunakan untuk mengukur sejauh mana aset perusahaan dibiayai dengan hutang. Dengan kata lain, leverage merupakan rasio yang digunakan untuk mengukur seberapa besar beban hutang yang harus ditanggung perusahaan dalam rangka pemenuhan aset. (Hery, 2015:190). Menurut penelitian Siregar \& Widyawati (2016) perusahaan yang memiliki hutang yang tinggi untuk pembiayaan operasionalnya dari pada pembiayaan yang berasal dari ekuitas, maka perusahaan tersebut memiliki tingkat tarif pajak yang rendah. Perusahaan yang memiliki hutang tinggi memanfaatkan bunga yang dihasilkan dari hutang (bunga pinjaman) agar pajak yang dibayar rendah karena bunga yang berasal dari hutang (bunga pinjaman) akan mengurangi laba sebelum kena pajak. Jadi semakin tinggi rasio leverage suatu 
perusahaan maka semakin tinggi beban bunga yang akan dibayar oleh perusahaan, sehingga beban pajak yang dikeluarkan rendah.

Penelitian terdahulu yang dilakukan oleh Calvin Swingly dan I Made Sukartha (2015) serta Judi Budiman dan Setiyono (2012) menemukan bahwa leverage berpengaruh signifikan terhadap tax avoidance. Mayangsari (2015) dan Riberio,et al (2015), menjelaskan bahwa semakin tinggi hutang yang dimiliki oleh perusahaan maka semakin rendah pajak yang akan dibayarkan oleh perusahaan. Artinya semakin tinggi hutang yang dimiliki oleh perusahaan maka akan semakin tinggi tingkat penghindaran pajaknya sehingga dapat disimpulkan bahwa leverage berpengaruh positif terhadap tax avoidance. Sedangkan pada penelitian yang dilakukan oleh Darmawan \& Sukartha (2014) menunjukkan bahwa leverage berpengaruh negatif terhadap tax avoidance.

Dalam penelitian ini, untuk menghitung leverage menggunakan proksi Debt to Total Asset Ratio (DAR). Menurut Kasmir (2008:156), Debt to Total Asset Ratio (DAR) adalah rasio utang yang digunakan untuk mengukur perbandingan antara total utang dengan total aktiva. Semakin tinggi rasio ini berarti semakin besar jumlah modal pinjaman yang digunakan untuk investasi pada aktiva guna menghasilkan keuntungan bagi perusahaan.

\subsection{Pengembangan Hipotesis}

Berdasarkan uraian di atas, maka dapat dirumuskan hipotesis dari penelitian ini adalah sebagai berikut:

1. H1: Capital intensity berpengaruh terhadap tax avoidance.

2. H2: Ukuran perusahaan berpengaruh terhadap tax avoidance.

3. H3: Leverage berpengaruh terhadap tax avoidance.

4. H4: Capital intensity, ukuran perusahaan, dan leverage secara simultan berpengaruh terhadap tax avoidance.

\subsection{Kerangka Hipotesis}

Berdasarkan penjelasan yang telah dipaparkan pada bagian sebelumnya, maka kerangka hipotesis dalam penelitian ini dapat digambarkan sebagai berikut:

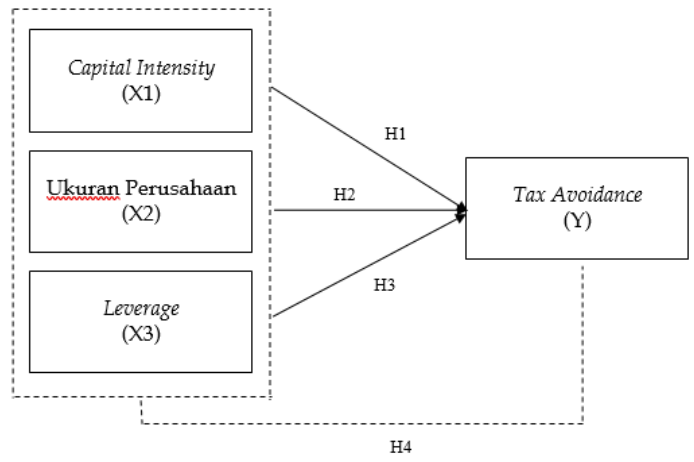

Gambar 1. Kerangka Hipotesis

\section{METODE PENELITIAN}

Pendekatan yang digunakan dalam penelitian ini adalah pendekatan kuantitatif yang berbentuk asosiatif karena penelitian ini bertujuan untuk mengetahui hubungan sebab akibat antara dua variabel atau lebih (Sugiyono 2013:55). Penelitian ini menjelaskan tentang pengaruh capital intensity, ukuran perusahaan, dan leverage terhadap tax avoidance.

Data yang digunakan dalam penelitian ini adalah data sekunder dari perusahaan yang terdaftar di Jakarta Islamic Index (JII) dengan mengakses website resmi BEI yaitu www.idx.co.id dan website tambahan yaitu www.idnfinancials.com. Populasi dalam penelitian ini adalah seluruh perusahaan yang sahamnya tercatat dalam Jakarta Islamic Index (JII) dengan kurun waktu tahun 2015-2019 yang berjumlah sebanyak 30 perusahaan. Sedangkan penarikan sampel penelitian ini 
dilakukan dengan menggunakan teknik purposive sampling, yaitu sampel dipilih dengan pertimbangan tertentu atau kriteria tertentu (Sugiyono, 2013:122). Tujuan menggunakan purposive sampling adalah untuk mendapatkan sampel yang representatif sesuai dengan kriteria yang ditentukan. Kriteria pemilihan sampel dalam penelitian ini adalah sebagai berikut:

1. Perusahaan yang tercatat dalam saham syariah yang terdaftar dalam JII periode 2015-2019.

2. Perusahaan memiliki data lengkap yang dibutuhkan dalam penelitian ini, meliputi laporan keuangan perusahaan yang berakhir pada 31 Desember serta secara konsisten terdaftar di JII selama tahun pengamatan.

3. Perusahaan yang menerbitkan laporan keuangan dalam mata uang rupiah.

4. Perusahaan yang tidak memiliki nilai laba komersial negatif agar tidak menyebabkan distorsi dalam penelitian.

Berdasarkan kriteria yang ditetapkan, diperoleh sampel sebanyak 11 perusahaan yang memenuhi kriteria dan ada 19 perusahaan yang tidak sesuai kriteria pemilihan sampel.

\subsection{Indentifikasi dan Pengukuran Variabel}

Variabel terikat (dependent) adalah variabel yang dipengaruhi atau yang menjadi akibat, karena adanya variabel bebas (independent) (Sugiyono, 2013). Variabel terikat dalam penelitian ini adalah tax avoidance yang diproksikan menggunakan current ETR (Effective Tax Rate). ETR menggambarkan persentase total beban pajak penghasilan yang dibayarkan perusahaan dari seluruh total pendapatan sebelum pajak yang diperoleh perusahaan (Yoehana, 2013). Rumus perhitungan current ETR menurut Siti Normala (2013) adalah sebagai berikut:

Current ETR = Beban Pajak Kini Laba Sebelum Pajak

Variabel bebas (independent) adalah variabel yang mempengaruhi atau yang menjadi penyebab terjadinya perubahan atau timbulnya variabel terikat. Variabel bebas dalam penelitian ini adalah capital intensity sebagai X1, ukuran perusahaan sebagai X2, dan leverage sebagai X3.

Capital intensity diproksikan menggunakan rasio intensitas aset tetap. Menurut Lanis dan Richardson (2011) dalam Husnaini et al (2013), rasio intensitas aset tetap digunakan untuk mengukur perbandingan aset tetap terhadap total aset sebuah perusahaan, di mana rasio ini menggambarkan proporsi atau seberapa besar aset tetap yang dimiliki perusahaan dari total asetnya. Rumus perhitungan rasio intensitas aset tetap menurut Lanis dan Richardson (2011) dalam Husnaini et al (2013) adalah sebagai berikut:

Rasio Intensitas Aset Tetap $=$ Total Aset Tetap Total Aset

Ukuran perusahaan diproksikan menggunakan logaritma natural aset tetap untuk mengetahui seberapa besar ukuran perusahaan melalui aset tetap yang dimilikinya. Delgado, Rodriguez dan Arias (2012) dalam penelitiannya menggunakan total aset sebagai penentu ukuran perusahaan dikarenakan perusahaan cenderung memiliki arus kas yang positif dan dianggap memiliki kinerja serta prospek yang bagus dalam jangka waktu yang lama bila total aset perusahaan tersebut besar jumlahnya. Rumus perhitungan ukuran perusahaan menurut Delgado, Rodriguez dan Arias (2012) adalah sebagai berikut:

$$
\text { Size }=\text { Ln }(\text { Total Aset Tetap })
$$

Leverage diproksikan menggunakan Debt to Total Asset Ratio (DAR). Menurut Kasmir (2008:156), Debt to Total Asset Ratio (DAR) adalah rasio utang yang digunakan untuk mengukur perbandingan antara total utang dengan total aktiva. Semakin tinggi rasio ini berarti semakin besar jumlah modal pinjaman yang digunakan untuk investasi pada aktiva guna menghasilkan 
keuntungan bagi perusahaan. DAR digunakan untuk mengukur mengukur seberapa besar jumlah aset perusahaan dibiayai dengan total hutang. Rumus perhitungan Debt to Total Asset Ratio (DAR) menurut Kasmir (2008:156) adalah sebagai berikut:

$$
\text { DAR }=\frac{\text { Total Hutang }}{\text { Total Aset }}
$$

\subsection{Analisis Data}

Pengujian hipotesis dalam penelitian ini dilakukan dengan analisis regresi berganda atau Multiple Regression Analysis (MRA). Multiple Regression Analysis (MRA) merupakan merupakan uji yang digunakan untuk mengetahui pengaruh variabel independent terhadap variabel dependent. Model regresi dalam penelitian ini adalah sebagai berikut:

$$
\mathrm{Y}=\mathrm{a}+\mathrm{b} 1 \mathrm{X} 1+\mathrm{b} 2 \mathrm{X} 2+\mathrm{b} 3 \mathrm{X} 3+\mathrm{b} 4 \mathrm{X} 4+\mathrm{e}
$$

\begin{tabular}{|c|c|}
\hline Y & $=$ Tax avoidance \\
\hline $\mathrm{a}$ & $=$ Konstanta \\
\hline X1 & $=$ Capital intensity \\
\hline $\mathrm{X} 2$ & $=$ Ukuran perusahaan \\
\hline $\mathrm{X} 3$ & $=$ Leverage \\
\hline b1 b2 b3 & $\begin{array}{l}=\text { Koefisien regresi } \\
=\text { Residual }\end{array}$ \\
\hline
\end{tabular}

Keterangan:

\section{HASIL DAN PEMBAHASAN}

Statistik deskriptif memberikan gambaran atau deskripsi suatu data yang dilihat dari nilai ratarata (mean), standar deviasi, varian, maksimum, minimum (Ghozali, 2012). Analisis statistik deskriptif dimaksudkan untuk memberikan gambaran dan karakteristik data dari sampel yang digunakan.

Berdasarkan tabel 1 dapat disimpulkan bahwa tax avoidance yang diproksikan melalui Effective Tax Rate (ETR) pada perusahaan yang terdaftar di JII tahun 2015-2019 rata-rata sebesar 0,1966945 dengan standar deviasi sebesar 0,10873031.

Perusahaan yang memiliki tax avoidance terkecil adalah yaitu PT Bumi Serpong Damai Tbk sebesar 0,00453 pada tahun observasi 2015. Perusahaan dengan tax avoidance terbesar dimiliki oleh PT Indofood Sukses Makmur Tbk yaitu sebesar 0,34872 pada tahun observasi 2015.

Tabel 1.

Statistik deskriptif

\begin{tabular}{l|r|r|r|r|r}
\hline & N & \multicolumn{1}{c}{ Minimum } & Maximum & \multicolumn{1}{c}{ Mean } & Std Deviation \\
\hline Tax Avoidance & 55 & .00453 & .34872 & .1966945 & .10873031 \\
\hline Capital Intensity & 55 & .19461 & .81139 & .5028773 & .15034850 \\
\hline Ukuran Perusahaan & 55 & 30.24816 & 33.49453 & 31.5463644 & .95419393 \\
\hline Leverage & 55 & .15715 & .74421 & .4804656 & .15762565 \\
\hline Valid N (listwise) & 55 & & & & \\
\hline Sumber: Data sekunder diolah menggunakan SPSS 25. & & &
\end{tabular}

Hasil statistik deskriptif di atas menunjukkan bahwa variabel bebas capital intensity memiliki nilai rata-rata sebesar 0,5028773 dengan standar deviasi sebesar 0,15034850. Perusahaan yang memiliki capital intensity terkecil adalah PT PP (Persero) Tbk yaitu sebesar 0,19461 pada tahun observasi 2015. Perusahaan dengan capital intensity terbesar dimiliki oleh PT Telekomunikasi Indonesia (Persero) Tbk yaitu sebesar 0,81139 pada tahun observasi 2019. 
Nilai rata-rata variabel bebas ukuran perusahaan sebesar 31,5463644 dengan standar deviasi yaitu sebesar 0,95419393. Perusahaan yang memiliki ukuran perusahaan terkecil adalah PT Kalbe Farma Tbk yaitu sebesar 30,24816 pada tahun observasi 2015. Perusahaan dengan ukuran perusahaan terbesar dimiliki oleh Astra International Tbk yakni sebesar 33,49453 pada tahun observasi 2019.

Variabel bebas leverage memiliki nilai rata-rata sebesar 0,4804656 dengan standar deviasi sebesar 0,15762565 Perusahaan yang memiliki leverage terkecil adalah PT Kalbe Farma Tbk yaitu sebesar 0,15715 pada tahun observasi 2018. Perusahaan dengan leverage terbesar dimiliki oleh PT Unilever Indonesia Tbk yakni sebesar 0,74421 pada tahun observasi 2019.

Setelah uji statistik deskriptif, selanjutnya dilakukan uji asumsi klasik yang terdiri dari uji normalitas, uji autokorelasi, uji multikolinieritas dan uji heteroskedastisitas.

Uji normalitas bertujuan untuk menilai sebaran data pada sebuah kelompok data atau variabel, apakah sebaran data tersebut berdistribusi normal ataukah tidak. Uji normalitas dilakukan dengan teknik uji Kolmogorov-Smirnov untuk mengetahui apakah data tersebut berdistribusi normal atau mendekati normal, level of significant yang digunakan adalah 0,05 .

Tabel 2.

Uji Normalitas

\begin{tabular}{lc}
\hline & $\begin{array}{c}\text { Unstandardized } \\
\text { Residual }\end{array}$ \\
\hline $\mathrm{N}$ & 55 \\
\hline Test Statistic & .128 \\
\hline Asymp. Sig. (2-tailed) & $.026^{\mathrm{c}}$ \\
\hline
\end{tabular}

Sumber: Data sekunder diolahmenggunakan SPSS 25

Berdasarkan tabel 2, diketahui bahwa Sig. (2-tailed) sebesar 0,026 lebih kecil dari 0,05. Hasil pengujian ini menunjukkan bahwa data yang dianalisis berdistribusi tidak normal, yang berarti sebaran data pada kelompok data tidak normal.

Uji multikolineritas bertujuan untuk menguji apakah antar variable bebas (independent) mempunyai hubungan langsung (berkorelasi) sempurna. Untuk mendeteksi ada atau tidaknya korelasi antar variabel bebas dapat dilihat dari nilai tolerance dan nilai Variance Inflation Factor (VIF). Jika hasil tolerance di atas 0,1 dan nilai VIF tidak lebih dari 10,.maka dikatakan tidak ada multikolinearitas.

Tabel 3.

Uji multikolinearitas

\begin{tabular}{l|c|c}
\hline \multirow{2}{*}{} & \multicolumn{2}{c}{ Collinearity Statistics } \\
\cline { 2 - 3 } & Tolerance & VIF \\
\hline Capital Intensity & .728 & 1.374 \\
\hline Ukuran Perusahaan & .763 & 1.310 \\
\hline Leverage & .943 & 1.060 \\
\hline
\end{tabular}

Sumber: Data sekunder diolah menggunakan SPSS 25.

Berdasarkan tabel 3, hasil uji multikolinearitas menunjukkan bahwa capital intensity memiliki nilai tolerance sebesar 0,728 dan VIF sebesar 1,374, ukuran perusahaan memiliki nilai tolerance sebesar 0,763 dan VIF sebesar 1,310, leverage memiliki nilai tolerance sebesar 0,943 dan VIF sebesar 1,060. Di mana jika nilai tolerance di atas 0,1 dan nilai VIF tidak lebih dari 10, maka tidak terdapat korelasi antara variabel bebas atau tidak terjadi multikolinearitas (Ghozali, 2013). 
Uji heteroskedastisitas bertujuan untuk menguji apakah dalam model regresi terjadi ketidaksamaan varian dari residual satu pengamatan ke pengamatan yang lain. Uji heteroskedastisitas dalam penelitian ini dengan melihat pada grafik scatterplot.

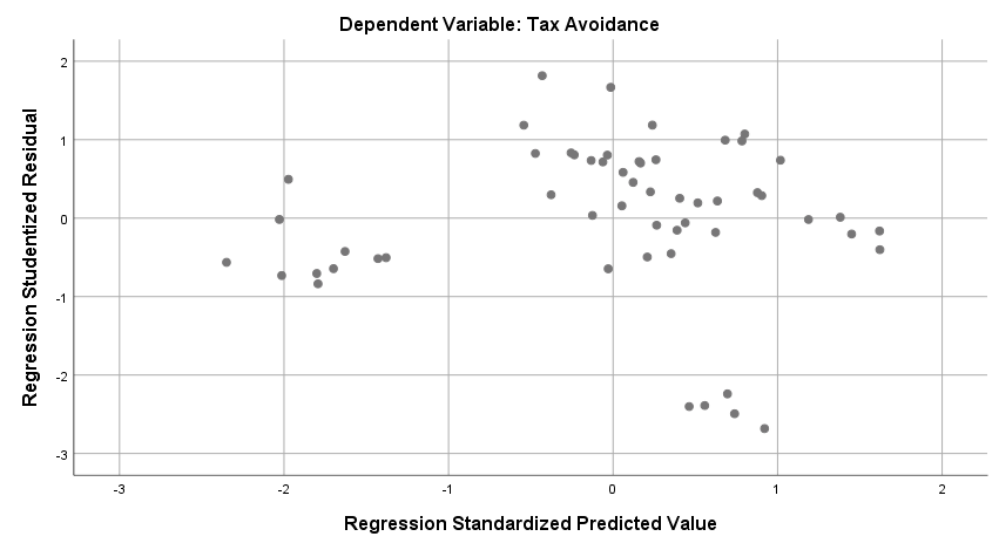

Gambar 2. Scatterplot

Berdasarkan gambar 2, dapat diketahui bahwa data tidak terjadi heteroskedastisitas sebab data menyebar dengan tidak membentuk pola yang jelas (seperti bergelombang, melebar, kemudian menyempit) serta titik-titik menyebar di atas dan di bawah 0 pada sumbu Y sehingga dapat disimpulkan bahwa tidak terjadi heteroskedastisitas pada model regresi.

Tabel 4. Dasar pengambilan keputusan

\begin{tabular}{|c|c|c|}
\hline Hipotesis Nol & Keputusan & Jika \\
\hline Terdapat gejala autokorelasi positif & Ditolak & $0<\mathrm{d}<\mathrm{dl}$ \\
\hline Terdapat gejala autokorelasi negatif & Ditolak & $4-\mathrm{dl}<\mathrm{d}<4$ \\
\hline Terdapat gejala autokorelasi positif & Tidak ada keputusan & $\mathrm{dl} \leq \mathrm{d} \leq \mathrm{du}$ \\
\hline Terdapat gejala autokorelasi negatif & Tidak ada keputusan & $4-\mathrm{du} \leq \mathrm{d} \leq 4-\mathrm{dl}$ \\
\hline Tidak ada autokorelasi & Diterima & $\mathrm{du}<\mathrm{d}<4-\mathrm{du}$ \\
\hline
\end{tabular}

Uji autokorelasi bertujuan untuk menguji apakah dalam model regresi linear ada korelasi antara kesalahan pengganggu pada periode $t$ dengan kesalahan pengganggu pada periode $t-1$ (sebelumnya) (Ghozali, 2013). Autokorelasi dideteksi ada atau tidaknya dengan cara melihat nilai Durbin-Watson (DW test) pada output. Kriteria pengujian pada hasil Durbin-Watson adalah sebagai berikut:

Dan hasil uji autokorelasi disajikan dalam tabel berikut:

Tabel 5. Uji autokorelasi

\begin{tabular}{|c|r|r|r|r|r|}
\hline $\begin{array}{c}\text { Mode } \\
1\end{array}$ & \multicolumn{1}{|c|}{$\mathrm{R}$} & R Square & $\begin{array}{c}\text { Adjusted R } \\
\text { Square }\end{array}$ & $\begin{array}{c}\text { Std. Error of } \\
\text { the Estimate }\end{array}$ & $\begin{array}{c}\text { Durbin- } \\
\text { Watson }\end{array}$ \\
\hline 1 & $.556^{\mathrm{a}}$ & .309 & .268 & .09300944 & .552 \\
\hline
\end{tabular}

Sumber: Data sekunder diolah menggunakan SPSS 25.

Berdasarkan tabel 5 dapat disimpulkan bahwa nilai DW test sebesar 0,552. Nilai ini jika dibandingkan dengan nilai tabel menggunakan derajat kepercayaan 5\% $(0,05)$ dengan jumlah sampel (n) sebanyak 55 serta variabel independent (k) sebanyak 3, maka di tabel Durbin-Watson akan didapat nilai du sebesar 1,6815 dan nilai dl nya sebesar 1,4523. Oleh karena nilai dw lebih 
kecil dari nilai $\mathrm{dl}(0<\mathrm{d}<\mathrm{dl})$ yaitu $0<0,552<1,4523$ maka dapat diartikan bahwa terdapat gejala autokorelasi positif sehingga keputusan $\mathrm{H} 0$ ditolak.

Teknik analisis data yang digunakan dalam penelitian ini adalah Multiple Regression Analysis (MRA) atau analisis regresi linier berganda dengan menggunakan program SPSS. Teknik ini digunakan untuk melihat pengaruh capital intensity, ukuran perusahaan, dan leverage terhadap tax avoidance pada perusahaan yang terdaftar di Jakarta Islamic Index (JII) periode 2015-2019. Hasil analisis regresi linier berganda dapat dilihat pada Tabel 6.

Berdasarkan tabel 6 dapat dibuat persamaan regresi sebagai berikut:

$\mathrm{Y}=0,233+0,329 \mathrm{X} 1-0,004 \mathrm{X} 2-0,176 \mathrm{X} 3+\mathrm{e}$

Persamaan regresi tersebut menunjukkan arah pengaruh variabel bebas capital intensity, ukuran perusahaan, dan leverage terhadap tax avoidance. Koefisien regresi variabel bebas yang bertanda positif berarti mempunyai pengaruh yang searah terhadap tax avoidance, sedangkan koefisien regresi variabel bebas yang bertanda negatif berarti mempunyai pengaruh yang berlawanan terhadap tax avoidance yang dijelaskan sebagai berikut:

Konstanta sebesar 0,233 menyatakan bahwa jika variabel Y dianggap konstan, maka tax avoidance sebesar 0,233. Koefisien regresi (X1) sebesar 0,329 menyatakan bahwa setiap penambahan 1 satuan akan meningkatkan tax avoidance sebesar 0,329\%.

Koefisien regresi (X2) sebesar -0,004 menyatakan bahwa setiap penambahan 1 satuan akan menurunkan tax avoidance sebesar 0,004\%. Koefisien regresi (X3) sebesar -0,176 menyatakan

Tabel 6. Uji Regresi Linier Berganda

\begin{tabular}{lr|r|r|r|r|}
\hline & \multicolumn{2}{c|}{ Unstandardized Coefficients } & Stand.Coefficients & & \\
Model & $\mathrm{B}$ & \multicolumn{1}{c}{ Std. Error } & Beta & \multicolumn{1}{c}{$\mathrm{t}$} & \multicolumn{1}{c}{ Sig. } \\
\hline 1 (Constant) & .233 & .456 & & .511 & .612 \\
\hline Capital Intensity & .329 & .099 & .455 & 3.355 & .002 \\
\hline Ukuran Perusahaan & -.004 & .015 & -.033 & -.244 & .808 \\
\hline Leverage & -.176 & .083 & -.255 & -2.127 & .038 \\
\hline
\end{tabular}

Sumber: Data sekunder diolah menggunakan SPSS 25.

bahwa setiap penambahan 1 satuan akan menurunkan tax avoidance sebesar $0,176 \%$.

Uji F bertujuan untuk melihat apakah semua variabel independent yang dimasukkan dalam model mempunyai pengaruh secara bersama-sama terhadap variabel dependent.

Berdasarkan tabel 7 dapat dilihat bahwa model persamaan ini memiliki nilai sig sebesar 0,000 yang lebih kecil daripada tingkat signifikansi $\alpha$ sebesar 0,05 yang berarti variabel independent secara simultan atau bersama-sama berpengaruh terhadap variabel dependent sehingga dapat disimpulkan model ini layak digunakan atau fit. Hal ini menjawab hipotesis 4 (H4) yaitu bahwa capital intensity, ukuran perusahaan, dan leverage secara simultan berpengaruh terhadap tax avoidance

Tabel 7.Uji F

\begin{tabular}{llr|r|r|r|r}
\hline Model & & Sum of Squares & df & Mean Square & F & Sig. \\
\hline 1 & Regression & .197 & 3 & .066 & 7.599 & $.000^{\mathrm{b}}$ \\
\cline { 2 - 7 } & Residual & .441 & 51 & .009 & & \\
\cline { 2 - 7 } & Total & .638 & 54 & & & \\
\hline
\end{tabular}

Sumber: Data sekunder diolah menggunakan SPSS 25. 
Uji R bertujuan untuk mengukur seberapa jauh kemampuan model menerangkan variasi variabel independent. Semakin tinggi nilai koefisien determinasi maka semakin tinggi kemampuan variabel independent untuk menjelaskan varibel dependent.

\begin{tabular}{ll|r|r|r}
\multicolumn{6}{c}{ Tabel 8. Uji R } \\
\hline \\
Model & $\mathrm{R}$ & R Square & \multicolumn{1}{c}{$\begin{array}{c}\text { Adjusted R } \\
\text { Square }\end{array}$} & \multicolumn{1}{c}{$\begin{array}{c}\text { Std. Error of the } \\
\text { Estimate }\end{array}$} \\
\hline 1 & $.556^{\mathrm{a}}$ & .309 & .268 & \multicolumn{1}{c}{.09300944} \\
\hline
\end{tabular}

Sumber: Data sekunder diolah menggunakan SPSS 25.

Berdasarkan tabel 8 menunjukkan bahwa besarnya nilai R2 sebesar 0,309 memiliki arti bahwa $30,9 \%$ variasi perubahan tingkat tax avoidance dipengaruhi oleh capital intensity, ukuran perusahaan, dan leverage. Sisanya sebesar $69,1 \%$ dipengaruhi oleh faktor-faktor lain yang tidak dimasukkan ke dalam model penelitian.

Uji t bertujuan untuk menunjukkan seberapa jauh pengaruh satu variabel independent secara individual dalam menerangkan variasi variabel dependent.

Tabel 9. Uji T

\begin{tabular}{|c|c|c|c|c|c|}
\hline \multirow[b]{2}{*}{ Model } & \multicolumn{2}{|c|}{ Unstandardized Coefficients } & \multirow{2}{*}{$\begin{array}{c}\text { Standardized Coefficients } \\
\text { Beta } \\
\end{array}$} & \multirow[b]{2}{*}{$\mathrm{t}$} & \multirow[b]{2}{*}{ Sig. } \\
\hline & $\mathrm{B}$ & Std. Error & & & \\
\hline Capital Intensity & .329 & .099 & .455 & 3.355 & .002 \\
\hline Ukuran Perusahaan & -.004 & .015 & -.033 & -.244 & .808 \\
\hline Leverage & -.176 & .083 & -.255 & -2.127 & .038 \\
\hline
\end{tabular}

Sumber: Data sekunder diolah menggunakan SPSS 25.

Berdasarkan tabel 9 menunjukkan bahwa variabel capital intensity memiliki nilai sig lebih kecil dari tingkat signifikansi $\alpha 0,05$ yaitu 0,002 yang berarti secara parsial variabel capital intensity berpengaruh signifikan terhadap tax avoidance. Hal ini dapat disimpulkan bahwa hipotesis satu (H1) diterima, yaitu capital intensity berpengaruh terhadap tax avoidance. Hasil penelitian ini sejalan dengan penelitian terdahulu yang dilakukan oleh Nyoman Budhi Setya Dharma \& Naniek Noviari (2017) serta Ria Rosalia Purnomo (2016) yang menemukan bahwa capital intensity berpengaruh signifikan terhadap tax avoidance.

Variabel ukuran perusahaan memiliki nilai sig lebih besar dari 0,05 yaitu 0,808 yang berarti secara parsial variabel ukuran perusahaan tidak berpengaruh signifikan terhadap tax avoidance. Hal ini dapat disimpulkan bahwa hipotesis dua (H2) ditolak, karena hipotesis dua dirumuskan bahwa ukuran perusahaan berpengaruh terhadap tax avoidance. Hasil penelitian ini membuktikan hasil penelitian yang dilakukan oleh Cahyono, Andini, dan Raharjo (2016) serta Ni Nyoman dan I Ketut (2014) yang menemukan bahwa ukuran perusahaan tidak berpengaruh signifikan terhadap tax avoidance.

Variabel leverage memiliki nilai sig lebih kecil dari tingkat signifikansi $\alpha 0,05$ yaitu 0,038 yang berarti secara parsial variabel leverage berpengaruh signifikan terhadap tax avoidance. Hal ini dapat disimpulkan bahwa hipotesis tiga (H3) diterima, yaitu leverage berpengaruh terhadap tax avoidance. Hasil penelitian ini sejalan dengan penelitian yang dilakukan oleh Calvin Swingly dan I Made Sukartha (2015) serta Judi Budiman dan Setiyono (2012) yang menemukan bahwa leverage berpengaruh signifikan terhadap tax avoidance. 


\section{KESIMPULAN}

Berdasarkan hasil analisis data dan pembahasan pada uji F, dapat diambil simpulan bahwa variabel bebas capital intensity, ukuran perusahaan, dan leverage secara simultan atau bersamasama berpengaru terhadap variable terikat tax avoidance. Maka hipotesis empat (H4) yang dirumuskan bahwa capital intensity, ukuran perusahaan, dan leverage secara simultan berpengaruh terhadap tax avoidance adalah benar.

Berdasarkan hasil analisis data dan pembahasan pada uji t, dapat diambil simpulan bahwa secara parsial variabel capital intensity berpengaruh signifikan terhadap tax avoidance, maka hipotesis satu (H1) yang dirumuskan bahwa capital intensity berpengaruh terhadap tax avoidance, diterima. Hasil penelitian ini sejalan dengan penelitian terdahulu yang dilakukan oleh Nyoman Budhi Setya Dharma \& Naniek Noviari (2017) serta Ria Rosalia Purnomo (2016) yang menemukan bahwa capital intensity berpengaruh signifikan terhadap tax avoidance.

Variabel ukuran perusahaan tidak berpengaruh terhadap tax avoidance, maka dapat disimpulkan bahwa hipotesis dua (H2) yang dirumuskan bahwa ukuran perusahaan berpengaruh terhadap tax avoidance, ditolak. Hasil penelitian ini membuktikan hasil penelitian yang dilakukan oleh Cahyono, Andini, dan Raharjo (2016) serta Ni Nyoman dan I Ketut (2014) yang menemukan bahwa ukuran perusahaan tidak berpengaruh signifikan terhadap tax avoidance.

Variabel leverage berpengaruh signifikan terhadap tax avoidance, maka hipotesis ketiga (H3) yang dirumuskan bahwa leverage berpengaruh terhadap tax avoidance, diterima. Hasil penelitian ini sejalan dengan penelitian yang dilakukan oleh Calvin Swingly dan I Made Sukartha (2015) serta Judi Budiman dan Setiyono (2012) yang menemukan bahwa leverage berpengaruh signifikan terhadap tax avoidance.

Berdasarkan hasil analisis dan simpulan di atas dapat diajukan beberapa saran bagi peneliti lain, yaitu dapat mempertimbangkan penambahan variabel lain yang belum digunakan dan memiliki pengaruh terhadap praktek penghindaran pajak perusahaan. Manajemen perusahaan diharapkan lebih memperhatikan setiap tindakan yang akan dilakukan beserta risiko yang akan ditanggung dari setiap keputusan yang dibuat sesuai dengan peraturan dan perundang-undangan perpajakan yang berlaku.

\section{DAFTAR PUSTAKA}

Adelina dan Theresa. 2012. Pengaruh Karakteristik Perusahaan dan Reformasi Perpajakan terhadap Penghindaran Pajak di Industri Manufaktur yang Terdaftar di Bursa Efek Indonesia tahun 2008-2010. Skripsi. Fakultas Ekonomi Universitas Indonesia Depok.

Ambarukmi, Diana. 2017. Pengaruh Size, Leverage, Profitabilty, Capital Intensity Ratio dan Actifity Ratio terhadap Effective Tax Rate (ETR) (Studi Empiris pada Perusahaan LQ-45 yang Terdaftar Di BEI Selama Periode 2011-2015).

Ana Ribeiro, Antonio Cerqueira, dan Elisio Brandao. 2015. The Determinants of Effective -Tax Rates: Firm' Characteristic and Corporate Governance. Journal of Economics and Management, University of Porto. ISSN: 0870-8541.

Ardyansah dan Zulkiha. 2014. Pengaruh Size, Leverage, Profitabilitas, Capital Intensity Ratio dan Komisaris Independen terhadap Effective Tax Rate (ETR). Diponegoro Journal of Accounting. Vol.3, No.2: 1-9.

Brigham dan Houston. 2006. Fundamental of Financial Management: Dasar-Dasar Manajemen Keuangan. Edisi 10. Jakarta: Salemba Empat.

Budiman dan Setiyono. 2012. Pengaruh Karakteristik Eksekutif terhadap Panghindaran Pajak. Simposium Nasional Akuntansi 15. Banjarmasin.

Daftar Saham Syariah Perusahaan JII. 2019. www.idx.co.id.

Darmadi, Iqbal Nul Hakim, dan Zulaikha. 2013. Analisis Faktor-Faktor Yang Mempengaruhi Manajemen Pajak dengan Indikator Tarif Pajak Efektif. Skripsi. Fakultas Ekonomi dan Bisnis Universitas Diponegoro Semarang.

Darmawan, I Gede Hendy, dan I Made Sukartha. 2014. Pengaruh Corporate Governance, Leverage, ROA, dan Ukuran Perusahaan Secara Parsial pada Penghindaran Pajak. EJurnal Akuntansi Udayana. Vol.9. No 1: 143-161. 
Dewi Dan Noviari. 2017 . Pengaruh Ukuran Perusahaan, Leverage, Profitabilitas dan Corporate Social Responsibility terhadap Penghindaran Pajak (Tax Avoidance) . Issn: 2302-8556. EJurnal Akuntansi Universitas Udayana. Vol.21. No 1. Oktober (2017): 830-859.

Dyreng, Hanlon dan Maydew. (2008). Long Run Corporate Tax Avoidance. The Accounting Review. Vol.83. No 1: 61-82.

Gupta dan Newberry. 1997. Determinants of Variability in Corporate Effective Tax Rates: Evidence from Longitudinal Data. Journal of Accounting and Public Policy. Vol.16. No $1: 1-34$.

Hanlon, Michelle., \& Heitzman, Shane. (2010). A review of tax research. Journal of Accounting and Economics. Vol.50.No.40:127-178.

Heryuliani, N. 2015. Pengaruh Katayeristik Perusahaan dan Kepemilikan Keluarga terhadap Penghindaran Pajak. Skripsi. Fakultas Ekonomi dan Bisnis Universitas Islam Negeri Syarif Hidayatullah Jakarta.

Hutagaol, John. 2007. Perpajakan Isu-isu Kontemporer, Jakarta: Graha Ilmu.

Jasmine, Ulfa 2017. Pengaruh Leverage, Kepelimikan Institusonal, Ukuran Perusahaan, dan Profitabilitas terhadap Penghindaran Pajak (Studi pada Perusahaan Manufaktur yang Terdaftar di BEI Tahun 2012-2014). JOM Fekon Vol.4 No.1.

Kalbuana, N., Purwanti, T., \& Agustin, N. H. (2017). Pengaruh Kepemilikan Manajerial, Beban Pajak Tangguhan, Dan Tingkat Pajak Efektif Terhadap Penghindaran Pajak Di Indonesia. MAGISTRA, 29(100).

Kalbuana, N., Solihin, S., Yohana, Y., \& Yanti, D. R. (2020). The Influence Of Capital Intensity, Firm Size, And Leverage On Tax Avoidance On Companies Registered In Jakarta Islamic Index (Jii) Period 2015-2019. International Journal of Economics, Business and Accounting Research (IJEBAR), 4(03).

Kalbuana, N., \& Aryadi, R. C. (2020). The Effect Of Audit Quality, Tax Avoidance, Leverage, And Presentation Of Other Comprehensive Income On Firm's Value In Jakarta Islamic Index Company. Journal of Islamic Economics Perspectives, 2(1), 1-10.

Kalbuana, N., Utami, S., \& Pratama, A. (2020). Pengaruh Pengungkapan Corporate Social Responsibility, Persistensi Laba dan Pertumbuhan Laba Terhadap Manajemen Laba Pada Perusaaan Yang Terdaftar di Jakarta Islamic Index. Jurnal Ilmiah Ekonomi Islam, 6(2), 350-358.

Kalbuana, N., Sutadipraja, M. W., Purwanti, T., \& Santoso, D. (2019). Pengaruh Profitabilitas, Leverage, Kinerja Lingkungan Terhadap Pengungkapan Islamic Social Reporting (Studi Empiris pada Perusahaan yang Terdaftar di JII Tahun 2013-2017). AKTSAR: Jurnal Akuntansi Syariah, 2(2), 233-248.

Kalbuana, N., Hastomo, W., \& Maharani, Y. (2020, November). Pengaruh Pengungkapan Islamic Social Reporting, Tingkat Pajak Efektif, Dan Beban Pajak Tangguhan Terhadap Penghindaran Pajak Di Indonesia Pada Perusahaan Di Jakarta Islamic Index. In Proseding Seminar Nasional Akuntansi (Vol. 3, No. 1).

Lanis, R. and Grant Richardson. 2011. The Effect of Board Director Composition on Corporate Tax Aggressiveness. Journal of Accounting and Public Policy. Vol 30.No.1. 50-70.

Mardiasmo. 2011. Perpajakan Edisi Revisi. Yogyakarta: Andi.

Mayangsari, Lillananda Putri dan Andayani. 2015. Pengaruh Good Corporate Governance dan Kinerja Keuangan terhadap Financial Distress. Jurnal Ilmu dan Riset Akuntansi, Vol.4 No.4.

Munawir, S. 2010. Analisis laporan Keuangan Edisi keempat. Cetakan Kelima Belas. Yogyakarta: Liberty.

Oktamawati, Mayarisa. 2016. Pengaruh Karakter Eksekutif, Komite Audit, Ukuran Perusahaan, Leverage, Pertumbuhan Penjualan, dan Profitabilitas Terhadap Tax Avoidance. Skripsi. Unika Soegijapranata.

Muzakki dan Darsono, (2015). Pengaruh Corporate Social Responsibility dan Capital Intensity Terhadap Penghindaran Pajak (Studi Empiris pada Perusahaan Manufaktur yang Terdaftar 
pada Bursa Efek Indonesia tahun 2011-2013). (Doctoral dissertation, Fakultas Ekonomika dan Bisnis).

Rego, Sonja Olhoft. 2003. Tax Avoidance Activities of U.S. Multinational Corporations. Contemporary Accounting Research. Vol. 20. No. 4, Winter 2003: 805-833.

Rodriguez and Arias. 2012. Do Business Characteristics Determine an Effective Tax Rate?. The Chinese Economy. Vol. 45. No. 6.

Sartono, Agus. 2008. Manajemen Keuangan. Yogyakarta: BPFE.

Sari, N., Kalbuana, N., \& Jumadi, A. (2016). Pengaruh Konservatisme Akuntansi, Kualitas Audit, Ukuran Perusahaan Terhadap Penghindaran Pajak (Studi Empiris pada Perusahaan Perdagangan Eceran yang Terdaftar di Bursa Efek Indonesia Tahun 2011-2015).

Siegfried. J.J. 1972. Effective Average U.S. Corporation Income-Tax Rates. National Tax Journal.

Siregar, R. dan Widyawati, D. 2016. Pengaruh Karakteristik Perusahaan Terhadap Penghindaran Pajak pada Perusahaan Manufaktur di BEI. Jurnal Ilmu dan Riset Akuntansi. Vol. 5. No. 2: $1-17$.

Resmi, Siti. 2014. Perpajakan Teori dan Kasus Edisi 8. Jakarta: Salemba Empat. Sugiyono. 2013. Metode Penelitian Pendidikan Pendekatan Kuantitatif, Kualitatif, dan R\&D. Bandung: Alfabeta.

Suwito, Edy dan Arleen Herawaty. 2005. Analisis Pengaruh Karakteristik Perusahaan terhadap Tindakan Perataan Laba yang Dilakukan Oleh Perusahaan yang Terdaftar di Bursa Efek Indonesia. Simposium Nasional Akuntansi VIII. Solo.

AR, Syamsuddin. 2006. Metode Penelitian Bahasa. Bandung: PT Remaja Rosdakarya.

Watts, Ross L. and Jerold L. Zimmerman. 1986. Positive Accounting Theory. USA: PrenticeHall.

\section{Biodata Penulis}

Rinosa Ari Widagdo, S.SiT.MA.Lahir di Madiun 13 Desember 1972. Memperoleh pendidikan Magister Ilmu Administrasi di Institut STIAMI di Jakarta, Saat ini sebagai dosen tetap di Politeknik Penerbangan Indonesia Curug.

Nawang Kalbuana, SE,Ak, M.Ak, CA, ACPA, BNT, Lahir di Klaten, 1 Januari 1981. Memperoleh pendidikan Sarjana Ekonomi Akuntansi dan Magister Akuntansi Konsentrasi Perpajakan di Universitas Mercu Buana Jakarta, serta Pendidikan Profesi Akuntan di Universitas Jenderal Soedirman - Purwokerto, Jawa Tengah. Saat ini sebagai Dosen tetap di Politekik Penerbangan Indonesia Curug dan Dosen tidak Tetap di Universitas Pramita Indonesia, ITB Ahmad Dahlan-Jakarta dan beberapa kampus swasta di wilayah Banten. Aktif melakukan publikasi baik di Jurnal Nasional Terakreditasi maupun di Jurnal Internasional Bereputasi.

Devia Rahma Yanti, Lahir di Jakarta, 15 November 1996. Memperoleh pendidikan SMK Akuntansi di SMK Citra Nusantara serta sedang menempuh pendidikan Sarjana Ekonomi Akuntansi di Fakultas Ekonomi dan Bisnis Universitas Pramita Indonesia Tangerang. Saat ini telah bekerja sebagai Accounting di PT Matahari Putera Prima, Tbk. 